\title{
PEACE AND JUSTICE IN THE GAMBIA: EXPANDING THE PEACEMAKING ROLE OF JUDGES
}

\author{
Haddy Roche \\ Gambia Judiciary
}

DOI: 10.46609/IJSSER.2020.v05i03.013 URL: https://doi.org/10.46609/IJSSER.2020.v05i03.013

\begin{abstract}
In many developing countries, the trend is to look to Western methods and standards when finding solutions to address the backlog of cases that plague the courts. The Gambia is no exception. This trend however appears oblivious of the fact that Western countries themselves are also plagued by backlogs in their courts. Due to the attachment to Western methods, there is hardly any inquiry into the benefits of local methods. This discussion is therefore about looking inwards to solve the problems caused by backlogs of cases in our courts. While it does not come claim a perfect solution to the problem of backlogs, it proposes an expansion of the peace making role of judges and the exploration of local methods of dispute resolution because that is essentially what many litigants will want.
\end{abstract}

Key words: courts, backlog of cases, local methods of dispute resolution

\section{Introduction}

Peace, according to many philosophers, is rooted in justice (Dietrich (2012, 2014, 2018); Galtung (1969) \& Lederach, 2003). Peace cannot be achieved without justice, and is inextricably linked to justice. The inextricable link between peace and justice is ably explained and rationalized by Porter (2015) thus:

"My main argument is that peace, justice, and reconciliation are interconnected, and while bringing them together is immensely difficult and rarely realized in full, the task is worth striving to achieve. Implicit in this argument is the view that degrees of enjoying peace with justice and reconciliation are to be valued, even if the realization is only partial. For example, there can be degrees of peace without justice

...but the peace will always be fragile because of the underlying feelings of injustices that abound.........similarly, justice without peace rarely is possible, because peace provides the 


\section{International Journal of Social Science and Economic Research}

ISSN: $2455-8834$

Volume:05, Issue:03 "March 2020"

conditions in which law and order can be restored and all forms of justice considered....." (pg.4).

Kerr \& Mobekk (2007) in discussing issues of justice and conflict in transitioning countries, also explain that peace, justice and reconciliation go hand in hand, and are mutually enforcing.

For clarity, justice, in the context of this article means both legal and social justice. Sardurski (1984) argues that legal justice is derived from social justice, therefore, legal justice and social justice are inextricably linked, and should not be distinguished from each other.

Courts are expected to render justice, and without justice from courts, there will be no peace in community. The value of justice to a peaceful and stable society is effectively captured by Keebler's (1930) contention that to promote and administer justice among men, is a primary concern of Government, and one of the three functions of the State, without which no organized society can exist.

A judge in court is therefore a peacemaker. However, the judge's role as a peacemaker is not sufficiently exposed and appreciated because of the limitations imposed by our adversarial system. In the adversarial system, the judge must render judgment in favour of, or against a party. In a way, this allows for some form of peace, because the judge has the final say, their orders and decisions must be complied with, and parties cannot take the law into their hands. However, as Galtung (1969) has taught us, peace is not only achieved by the absence of war, but also by the presence of conditions, structures, systems and cultures that make peace possible. Therefore, the type of peace resulting from a judge's decision, while ending the dispute in theory and achieving some form of peace, in practice still leaves underlying tensions, because one of the parties will be the "loser", and so will inevitably be resentful. The form of peace achieved only means that the dispute is brought to an end, but not the relationship of the parties. It does not mean that the parties have a harmonious relationship of mutual understanding and respect for each other. Such a peace although satisfactory to some, does not ensure the parties have a relationship after the case ends, and so it does not allow conditions for constructive and genuine peace between the parties. It can best be described as a superficial peace, because currents of bitterness and resentment underlie it.

Davidheiser (2007), in his study of governance and legal reform in The Gambia, effectively portrayed the superficial peace created under the adversarial system by quoting a Gambian Mandinka Man in his sixties by the name Mankanding, who said:

'When people go to the police and courts the young ones will see this and feel that there are divisions among us, between families or whomever, and people will be separated and 


\section{International Journal of Social Science and Economic Research}

ISSN: $2455-8834$

Volume:05, Issue:03 "March 2020"

isolated. For example, if I have a problem with you [ and I go to the legal system], and later you have something that I need, then I will not be able to come to you and borrow it and vice versa. My going to the police and courts could even cause separation between our families which would lead to more problems for everyone. Even if you happen to win in the courts, you will lose in the long run. That is why it is better to handle things in our local way here.' (pg 10).

Despite that section 24 of our 1997 Constitution makes it mandatory for any court or adjudicating authority established by law for the determination of any civil or criminal matter to be independent and impartial, even where the court is independent and impartial, the "loser" in most cases is resentful. Therefore, although section 24 of the Constitution should assure parties that their disputes will be fairly determined, and so should ensure peace between them at the end of their case, in reality, it does not do so. Indeed, it has been said that humans are not designed to accept defeat easily (Polivy and Herman, 2002), and so every defeat would trigger a need to keep on fighting.

Consequently, the role of the judge as peacemaker is often overshadowed and obscured (if not negated), by the fact that the disputes he resolves will most often in practice, pull the parties further apart rather than bring them together. In the adversarial system there is inevitably a "winner" and a "loser". And even if a judge's decision is subject to appeal, there is also a winner and a loser in the appellate courts. Most people do not take losing very well, and so the win/lose ending means a party (the loser) will be aggrieved, and hence a further deterioration of the relationship. A system where a dispute is resolved but leaves the relationship of the parties fragile or more damaged is not ideal for peace and stability.

Our adversarial system is a win/lose orientation to conflict, which Deutsch et al (2011) believe restricts a constructive peaceful resolution. They emphasize that a cooperative or win/win orientation to conflict resolution is more constructive than a competitive or win/lose orientation to conflict, because in a cooperative or win/win orientation to conflict there is no winner or loser. They advance that in the win/lose orientation, each party is focused on winning, and so there is no open communication, no trust and no mutual understanding. A win/win approach to conflict on the other hand, greatly facilitates resolution because the parties communicate, and this enables them gain better and deeper insight about the dispute and about each other. Their views about the issues in dispute and each other are improved and enriched, to the extent that cooperation, rather than winning or losing is more central to them (Deutsch et al, 2011). The same view is held by Connors (2014), who also observed that the adversarial system emphasizes individualism, competition and autonomy which harm relationships. Thus, a win/win approach to conflict 


\section{International Journal of Social Science and Economic Research}

ISSN: $2455-8834$

Volume:05, Issue:03 "March 2020"

leaves the parties equally satisfied, or ensures a balance in their relationship to the extent that neither of them will feel resentful.

In the adversarial system, the role of the judge as a peacemaker can also be obscured and curtailed by the concept of judicial independence. The concept of judicial independence has long been a subject of debate, and some will argue that judges are not really independent (Frank, 1931). I will not address that debate and arguments related to it in this article. For the purposes of this article, the point to make is that the concept of judicial independence dictates that a judge's duty is simply to apply the facts and the law, not apply his emotions, intuitions, personal beliefs and values as a peacemaker would do. However, peace philosophers are generally agreed that peacemakers can, and should invoke their emotions, intuitions, personal beliefs, values- even imagination and creativity, to understand the parties and resonate with them (Dietrich, 2014; Lederach, 2005). If the peacemaker understands the parties and resonates with them, then the peacemaking task becomes easier and the conflict can be resolved appropriately to address the parties' needs and interests.

The judge's role as a peacemaker in the adversarial system is further obscured and negated by the fact that he sits in a court, which is a formal institution meant for an adversarial system of handling disputes, and so parties are competitive, often formal, tense, deferential and inhibitednot encouraged to be free and to reveal their true selves. The judge is isolated, and sits on a higher platform above everyone else-literally on a pedestal, where he follows rules that essentially allow him to head and dictate the proceedings. On the other hand, peacemakers will put themselves on the same level as the parties (Dietrich, 2014). They will not necessarily follow rules, and they will try to establish a connection to the parties and the dispute, and would let the proceedings flow freely and informally, creating a safe space for the parties to feel at ease and uninhibited (Lederach, 2003). In peacemaking, connection between the parties and the peacemaker is especially important for the peacemaker to effectively address the parties' needs and interests so that the parties are equally satisfied at the end of the process. In the adversarial system if the judge tries to establish a connection, they will be accused of descending into the arena of conflict, and not being detached from the parties and the conflict.

\section{The case for expanding the peacemaking role of judges}

Davidheiser (2007), underscores that research shows that most Gambians consider the courts an "alien domain" and that the courts in Gambia are not really responsive to the needs and desires of many Gambians. He observed that the Western style adversarial court system does not elicit the trust and confidence of Gambians as much as traditional grassroots methods do. He reports that the Western adversarial system is not much appreciated by most Gambians, and is not 


\section{International Journal of Social Science and Economic Research}

ISSN: $2455-8834$

Volume:05, Issue:03 "March 2020"

effective for meeting local expectations and achieving stable governance. He therefore suggests that The Gambian justice system should include more local conflict resolution methods rather than focus mainly on the Western adversarial method. He put it as follows:

"The potential for sustainable development and stable governance will be greatly increased if reform is geared toward integrating national bureaucratic systems with local values and priorities. Rather than focusing simply on courts and other familiar fora, efforts could be made to draw on local practices that are potentially participatory in nature, providing a discursive arena for debate and dispute processing. Open and transparent dispute management procedures can supply a social space for residents to discuss their conflicts, plans, policy wishes, and strategies for policy implementation.” (pg 3).

Because judges in the adversarial system are restricted, the peace they achieve is also limited, and is not as constructive as it can potentially be. Yet, it is crucial that the peace emanating from a judge's decision be constructive and sustainable if it is to be meaningful, and if it is to foster a harmonious society. A harmonious society is a less litigious society, and a less litigious society means less workload for judges. Less workload for judges means timely and higher quality judgments from them, which in turn means a more satisfied public and a more peaceful society.

There is need to temper the restrictions placed on the judge in the adversarial system. Since there is no chance of moving away from the adversarial system anytime soon, a way forward could be to establish a system which allows the judge's role as peacemaker to be adequately expanded and manifested in the adversarial system. If judges are to live up to their name as peacemakers, they should be seen making real peace, which means constructive peace. Connors (2014) justifies the need to temper the restrictions placed on a judge by the adversarial system as follows:

“Current state of court justice systems are structured around 'either-or' decision making. The adversarial system looks at problems through the narrow lens of X vs, Y, guilty or not guilty. An individual or relationship is then judged and labelled solely by a single event. The label replaces the person, and we are prevented from solving the whole problem and all that underlies it.

Current systems create division within the community. When we label an individual, we separate and isolate him from the community. He is no longer a colleague, neighbor, or community member, but a juvenile delinquent, felon, offender, neglectful parent, or abusive spouse. The justice system sets him aside and the community will continue to exclude, divide, and separate itself from the person. 


\section{International Journal of Social Science and Economic Research}

ISSN: $2455-8834$

Volume:05, Issue:03 "March 2020"

Labelling and dividing continue the cycle of wrongdoing. By labeling, separating and dividing, we do nothing to restore the individual, the community, and the actual harm that was done. Neither the person who caused the problem nor those who were impacted get their needs met by decisions that seek to punish without repairing harm and restoring relationships.

Because we've resolved and restored nothing, the individual eventually accepts the label as truth and continues to live accordingly. This leads to recidivism, polarization, and harmful relationships that tear the fabric of family and community. It is why we can expect the majority of children who enter the justice system to reenter the system. It is why disputing families leave the courtroom more polarized than when they entered." (para 21- sub- heading 4).

Sasson \& Sydow (2017) in their support of the Peacemaking Court System as opposed to the adversarial system, echoed Connors by adding:

"The adversarial system typically focuses on assigning guilt and meting out punishment, while peacemaking seeks to achieve the long-term healing of relationships. Most often, the adversarial system tends to isolate the defendant, assigning an attorney to speak for the defendant in court and to negotiate with opposing counsel. The defendant is encouraged to remain silent, for fear that anything said may be used to incriminate.

Indeed, most defendants go through the Western criminal justice system never having told their story to anyone, except perhaps defense counsel. If sentenced to jail, the defendant is then physically separated from the community, furthering his or her isolation. By contrast, peacemaking encourages defendants (as well as victims, family members, and community members) to express themselves freely, and the entire process is premised on each person's equal participation. It emphasizes the defendant's relationship with the broader community, and tries to rebuild those relationships instead of severing them further." (pg.1).

Connors (2014) also laments that judges will often judge who, what, when, where, and how, but seldom the why of an event. Yet he believes that the concept of justice should be more than that, because we are all connected. He believes that judges (like everyone else), will be impacted by the actions they take and decisions they make. Therefore, judges should be guided by the awareness that we are all intricately intertwined, and that all action they (the judges) takehealing or harmful, has a profound ripple effect on others in the community, and will also inevitably lead back to them (the judges) as members of the same community (Connors, 2014). Therefore, according to Connors (2014), a judge must act responsibly, and one way a judge can show that he is acting responsibly, is by taking the time to ask for the why. 


\section{International Journal of Social Science and Economic Research}

ISSN: $2455-8834$

Volume:05, Issue:03 "March 2020"

Asking for the why however, is not the traditional role of the judge, and is more common in other peacemaking forum where the peacemaker should elicit the route to the conflict, and achieve a resolution of the conflict by addressing all its themes and layers (see Dietrich, 2014, 2018; Lederach, 1997). The judge on the other hand, is expected to stick to the facts and evidence before him, otherwise they can be accused of fishing for evidence and acting outside the evidence. Therefore, judges cannot act as responsibly as Connors (2014) would want them to because they will be accused of descending into the arena and being biased.

The question to be asked then is: How can the restrictions on the peacemaking capacity of a judge be tempered so that the peacemaking role of the judge can be effectively expanded, manifested and secured? The aim of this article is to suggest an answer to the question by floating the idea of a Peacemaking Forum. This idea is inspired by the Peacemaking Court System found in the Navajo judicial system which is becoming increasingly popular in the North American justice system (Sydow, 2018). Davidheiser (2007) in his same study about governance and legal reform in The Gambia, suggests that the Navajo Peacemaker Court System is one promising way of overcoming the negative effects of the Western adversarial system in The Gambia, as it is more transparent, ensures the incorporation of local customs and practices, and ensures local participation to ensure that parties have a healthy relationship after their case is determined.

\section{The Peacemaking Court System}

Zion (2005) explains that under this system, Peacemaker Court Rules (PCR) are put in place, so that if the judge in the adversarial court decides that the case is appropriate for peacemaking, they will refer it for peacemaking to the Peacemaking Court. Connors (2014) identifies three instances where referral to the Peacemaking Court is especially appropriate:

- Where there would be an ongoing relationship between the parties in conflict after the court adjudicates the conflict

- Where the person harmed is in need of a deeper understanding of the cause of harm in order to move forward

- Where the community and the individual who caused the harm need a deeper understanding of the cause and effect of the harm within the community

Zion (2005) explains that this system allows the blending of traditional peacemaking methods with regular court operations, so that if the referring court decides that the case is of a type that should be settled by peaceful means in the Peace Court, it can appoint "Peacemakers" or a 


\section{International Journal of Social Science and Economic Research}

ISSN: $2455-8834$

Volume:05, Issue:03 "March 2020"

"Peacemaker" from among members of the community to resolve the case by traditional peaceful means.

Under the Peacemaking System, the appointment of a Peacemaker is not haphazardly done, a Peacemaker must be a person with a reputation for integrity, honesty, humanity and ability to resolve problems. Nielsen (1999) explains that:

"The Peacemakers are respected members of the ... community, male and female, who are chosen by their communities because they have 'demonstrated character, wisdom and the ability to make good plans for community action' (Austin 1993;10). They may have blood or clan relationship with the disputants or they may be community members, but either way, they are not neutral mediators. They are guides and teachers..." (Pg. 110).

Deutsch et al (2015) believe that for a cooperative win/win result, it is necessary for the parties and the peacemaker to be part of the same community and share similar orientations. This according to them, will enable the peacemaker easily determine and extend the necessary support to the parties for a peaceful resolution.

Nielsen (1999) points out that the Peacemaking Court system does not exclude spirituality. He explains that the peacemaking session will often start with a prayer by the Peacemaker or by a senior family member (of any of the parties), to "summon spiritual assistance and participation, and to focus the mind of the participants on the proceedings" (Pg. 111). He says the Peacemaker can also use spiritual narratives to help parties achieve consensus, harmony and forgiveness. The invocation of spirituality pointed out by Nielsen, is in line with the recommendation of notable peace philosophers (for example Dietrich 2013, 2014; Lederach, 2003, 2005), who believe in the use of multiple strategies in peacemaking, including the invocation of spirituality. They believe that spirituality in any or all forms can be a useful tool in peacemaking, as it often resonates with parties and the peacemaker, and so can inspire both to a peaceful resolution.

The Peacemaking System will therefore be based on the basic tools and methods for achieving genuine, constructive and sustainable peace as recommended by peace philosophers. Therefore, it gives judges the opportunity to participate in genuine, constructive and sustainable peacemaking. By referring the matter to the Peace Forum, the judge's limited peacemaking role is expanded. In this system, the judge will not only facilitate peacemaking by referring the matter to the Peace Forum, they will also be participating in the proceedings of the Peacemaking Forum, because the proceedings of the Peacemaking Forum will be under their supervision, and will also be subject to their enforcement powers. In effect, the judge and the Peacemaker will be working together for a peaceful resolution of the matter referred to the Peacemaker. 
International Journal of Social Science and Economic Research

ISSN: 2455-8834

Volume:05, Issue:03 "March 2020"

\section{Perks of the Peacemaking Court System}

The Peacemaking Court System is a flexible system. The referring court (which in our case I would suggest to be the High Court or Magistrates' Court), does not have the sole power to select a Peacemaker. The parties in the dispute are also free to select a Peacemaker of their choice if the Peacemaker selected by the judge is not suitable to anyone of them. The Peacemaker being familiar to both parties, will be able to navigate through their issues easily, and so there is a lesser chance that their dispute will be intractable. A Peacemaker once selected, will conduct the peacemaking process using traditional methods of the community, and will report back to the referring court which has supervisory powers over him. The peacemaking process is open to the community, and the Peacemaker can invite family members and any member of the community with an interest in the dispute to attend the proceedings and have their say, and to encourage the parties to a peaceful resolution. Community participation, and participation of the parties is strongly recommended by Lederach (1998), who he believes that the community and the parties can be the best resource for coming up with a resolution.

Although the proceedings in the Peacemaking Court are not formal, and the Peacemaker works with the judge and parties to find a solution to the dispute rather than impose a judgment, it becomes obvious that one valid criticism about such a system is that the peacemaking forum which the judge refers the matter to is called a "court", which would give the impression that the Peacemaking System is not too different from the adversarial system it aims to improve. This being the case, I am more amenable to the idea of a Peacemaking Forum rather than a Peacemaking Court. In our case, the suggestion will be for the matter to be referred to a Peacemaking Forum rather than a Peacemaking Court.

Giving judges the discretion to refer matters to a Peacemaking Forum is certainly one way of giving them the opportunity to manifest and expand their peacemaking role. The judge's referral of the matter to the Peacemaking Forum creates a greater opportunity for peace because the parties will have the freedom to choose a peacemaker they are familiar with. If the parties are familiar with the peacemaker, they will feel they are in a safe space, and they will feel more at ease and less inhibited to express themselves and their feelings during the process. If they are at ease and can express themselves, then there will be greater opportunity for empathy and understanding between them, their dispute will be less intractable, and there will be a greater opportunity for a peaceful resolution of their dispute (Lederach, $2003 \& 2005$ ).

The peacemaking process in the Peace Forum does not require the parties or their witnesses to be in witness box and thrust as rivals on opposite sides, several feet away from each other, having to look across the room several feet away to be able to see each other, and then seeing each other as 


\section{International Journal of Social Science and Economic Research}

ISSN: $2455-8834$

Volume:05, Issue:03 "March 2020"

the adversary or demon. Rather, the parties and their witnesses will be brought together and put together on one and the same side, and given the opportunity to work together with the Peacemaker to come up with a solution for their dispute. By being put together on the same side and made to work together, there is greater potential for them to develop mutual insight, empathy and understanding. Mutual insight, empathy and understanding will foster a greater chance for a peaceful resolution of their dispute. Consequently, the Peacemaking System allows for relationship building, which, according to Lederach (1997, 1998, 1999 \& 2005) and Mitchel (2002), is fundamental to genuine and sustainable peace.

As stated, the Peacemaking System does not exclude spirituality. This should make it attractive for this jurisdiction. The Gambia is a secular state, but Gambians are spiritual (in religious terms). Pew Research Center (2010) found that 95.1\% of the Gambian population is Muslim, and over $4.5 \%$ of the Gambian population is Christian. Therefore, invoking spirituality (especially religious spirituality) in the peacemaking process, should be appealing to many parties in conflict, and should facilitate the chances of a peaceful resolution. In the adversarial system, the only opportunity the parties have to invoke spirituality is when they are sworn on the Quran or Bible, or when they affirm before they testify. Moreover, as stated, in the adversarial system only the law and the facts are relevant, spiritual narratives would be irrelevant, and hence the lesser the chances of a spiritual motivation to a peaceful resolution.

Of course, in this jurisdiction, we also have the Cadi Courts (Islamic Courts) where spirituality (Sharia Law) governs the proceedings. Therefore, it could be argued that if the parties want spiritual guidance they should take their cases to the Cadi Courts. However, section 137 of the 1997 Constitution limits the jurisdiction of the Cadi Courts only to matters of marriage, divorce and inheritance where the parties are Muslims. As the above-mentioned statistics by Pew show, not all the Gambian population is Muslim. Moreover, matters to be referred to the Peace Forum would be matters that the referring court (not the Cadi Court) would have jurisdiction over.

Apart from effectively manifesting and expanding the peacemaking role of the judge, such a peacemaking system will help mitigate the backlog of cases, and so improve access to justice in some of our courts. There is still a backlog of cases in some of our courts, and this is despite that we have the Alternative Dispute Resolution Actof 2005, which provides an alternative dispute resolution system in The Gambia. The Act established an Alternative Dispute Resolution Secretariat, and any court in The Gambia,with the consent of the parties, and the parties themselves may refer any matter for Arbitration, conciliation or mediation.

The Alternative Dispute Resolution Secretariat has been operating since 2008. And, it was reported in The Point Newspaper (Baldeh, 2016), that the Chief Executive of the Alternative 


\section{International Journal of Social Science and Economic Research}

ISSN: $2455-8834$

Volume:05, Issue:03 "March 2020"

Dispute Resolution Secretariat, while reporting on the activities of the Alternative Dispute Resolution Secretariat in 2014, disclosed to the National Assembly that the majority of the 581 cases handled by the Alternative Dispute Resolution Secretariat since its inception in 2008 were effectively resolved, and that Alternative Dispute Resolution works well in both urban and rural areas of the Gambia. However, the findings of the West African Law Institute (n.d.) as reported by the United Nations Development Program on their website, are that the Alternative Dispute Resolution Secretariat is not as effective as it can be because a vast number of Gambians living outside the greater Banjul area are unaware that they have the alternative of taking their disputes to alternative dispute resolution, and don't know the value of taking their disputes to alternative dispute resolution.

The West African Law Institute also found that there is some resistance to alternative dispute resolution, especially from the legal sector, because the Alternative Dispute Resolution Secretariat is not a body independent from government, but is attached to the Ministry of Justice. They also found that parties who participated in alternative dispute resolution through the Secretariat, had problems enforcing agreements reached. Moreover, one of the methods for resolving disputes under the Act (at chapter 2), is through Arbitration proceedings, which are formal proceedings, requiring inter alia the presentation of statements and evidence, and the involvement of an arbitral tribunal and arbitral panel to determine the dispute.

Furthermore, concepts such as mediation and conciliation as stipulated in the Act (at chapters 3 and 4), are not focused on building the relationship of the parties, or ensuring that the parties have a harmonious relationship after the resolution of their dispute. They are simply focused on resolving the dispute at hand and nothing more. The Act mentions nothing about building harmonious relationship between parties. Therefore, it does not fully represent the traditional indigenous non-professional peacemaking methods that the Peacemaking System aims to promote. A Court Connected ADR system was created by Practice Direction No.1 of 2013 to allow judges to refer appropriate cases to alternative dispute resolution, but it has not yet positively impacted in on efforts to reduce backlog.

Sasson \& Sydow (2017), in their guide to the Peacemaking Court System, explain that the Peacemaking System is different from other forms of alternative dispute resolution (such as mediation or negotiation) which are handled in an Alternative Dispute Secretariat. They explain that in such other forms of alternative dispute resolution, the central focus is on the dispute at hand, the focus is not on healing the relationship of the parties, and each party is typically expected to give up something. On the other hand, in the Peacemaking System, the focus is more on creating a lasting harmonious relationship between the parties rather than on resolving the 


\section{International Journal of Social Science and Economic Research}

ISSN: $2455-8834$

Volume:05, Issue:03 "March 2020"

dispute at hand (Sasson \& Sydow, 2017). While other forms of alternative dispute resolution such as mediation and negotiation will resolve disputes, they also leave the relationship of the parties fragile and vulnerable, and so do not ensure constructive peace.

There will surely be arguments that the Peacemaking System would be a waste of time and money. As a matter of fact, there are already too many courts and tribunals established, but to no avail, as the back logs of cases persists. My response to such argument however, will be to state the obvious, which is, the fact that backlogs persist despite the numerous courts established, is more than anything a clear indication that the exploration must continue, and it is time to consider other ways of addressing the backlogs, and the Peacemaking System might likely be one other way of effectively mitigating the backlogs.

It is true that the records of the superior courts of The Gambia, show that the courts (especially the Supreme Court and Court of Appeal) have effectively cleared backlog of cases between 2017 and 2018. However, the same records will also show that there is still a backlog of cases in the High Court and Magistrates' Court. Sometimes cases in the High Court drag on unnecessarily simply due to the rigid rules we have in the adversarial system. I, for example, inherited a High Court case four years after its inception. The pre-trial process is still on going about five years after its inception, and this is mainly due to the technicalities it comprises. Technicalities and rigid procedures in the adversarial system therefore contribute to the building up of backlogs.

Presently, there are statutory provisions which direct judges to encourage and promote reconciliation and peace between the parties- for example, Order 1 Rule 3 of the High Court Rules First Schedule provides that:

A judge shall, in an action pending before him or her-

(a) Promote conciliation among the parties; and

(b) Encourage and facilitate the amicable settlement of the case

Also, Rule 14 (c) of the High Court (Amendment) Rules, 2013 provides that the judge in pre-trial conference shall settle the issues for trial to ensure that only contentious issues go to trial, and under Rule 14(d) the judge can refer the suit to alternative dispute resolution for possibility of an amicable settlement. While these provisions direct the judges to encourage peaceful resolution of disputes, they give no such directions to the parties and their counsel. Therefore, judges cannot do much to ensure peaceful resolution of cases. They cannot force parties to choose a peaceful resolution to their case. Their efforts are sometimes frustrated, not only by recalcitrant parties but also by recalcitrant counsel. Accordingly, even as judges do their best to avoid backlogs, backlog 


\section{International Journal of Social Science and Economic Research}

ISSN: $2455-8834$

Volume:05, Issue:03 "March 2020"

exist. Indeed, many counsel will diligently prosecute their cases, but there is still a backlog of cases. Clearly, we must continue to explore better ways of improving access to justice in this jurisdiction.

\section{Challenges facing a Peacemaking Court System}

There are bound to be questions about the enforceability of the process. Zion (2005) however explains that under this system, the parties are free to reject the process before the end. However, once they agree to it, they would be subject to the referring court's normal enforcement powers, including the powers to compel attendance. And if the matter proceeds to the end, the parties will be subject to the referring court's powers to enforce agreements -including agreements for restoration.

Another issue would be the payment due to the Peacemakers for their services. Under the Navajo Peacemaking System, the Peacemaker is paid a token sum by the parties, not by the referring court or government. This might be one reason why such a system might not be popular with litigants in this jurisdiction. First of all, what is a "token sum"? And how is it to be determined? Litigants who have already paid lawyer's fees might be reluctant to spend more money. Certainly, the obligation to pay the Peacemaker a token sum can cause a party to reject the alternative of the Peacemaking process.

Some might therefore argue, that in this jurisdiction, the idea of a Peacemaking Forum would be more suitable for cases that fall under the jurisdiction of the Magistrates' Courts, where parties are not obliged to pay for the services of a lawyer to represent them, and where many parties do not pay for the services of a lawyer to represent them. It is however my suggestion that, if lawyers take into account the possibility of having to pay a token sum to the Peacemaker when they are charging their clients, and then include that token sum in their clients' bills, then the responsibility of paying the Peacemaker such token sum will fall on the lawyers not the clients. Then clients cannot reject the idea of referring the matter to the Peacemaker simply because it will mean additional expense for them, and lawyers also cannot reject the idea of referring the matter to the Peacemaker on the basis that it is not covered in their bills. However, a lawyer's bill might drastically increase if the token sum is added, and so might be unaffordable to the client and will be rejected by the client.

The suggestion will be for special funds to be set aside by the judiciary to cover the token sum payable to the Peacemaker both in the High Court and Magistrates' Court. A better alternative might be to secure independent funding to pay Peacemakers. This should ensure that the Peacemaker remains independent. Nevertheless, what is a "token sum" or the sum to be paid to the Peacemaker, will still have to be determined, and that might be a big challenge. 


\section{International Journal of Social Science and Economic Research}

ISSN: $2455-8834$

Volume:05, Issue:03 "March 2020"

Another issue will be the appointment of the Peacemakers who will be available for selection by the judge. While the judge and the parties will be free to select a Peacemaker, there must be appointed Peacemakers from among who they will make their selection. This will beg the question: who will be the appointing authority? Moreover, the appointment process must be apolitical, fair and transparent to be credible. It will be a great challenge to ensure that it is so, as we live in a political and connected world. But it can be done, as it is supposedly done in the appointment of judges and other judicial officials. The Peacemakers have to possess vast knowledge of local traditional peacemaking procedures, practices and strategies if they are to be effective. They will require training. Trainers will have to be appointed to train them, and training facilities will have to be established for them. These are other expenses and logistical issues to consider.

As stated, one of the reasons for the Navajo having such a system is to ensure that their peacemaking traditions remain relevant. Therefore, in our case, the system could be opposed on the ground that we already have District Tribunals which decide cases informally according to the customs and practices of their community (see sections 11(a) and section 20 of the District Tribunals Act Cap 6:03 Laws of The Gambia). However, the customs and practices employed by District Tribunals do not always lead to peaceful results, and like in the adversarial system, there is almost always a "loser" and a "winner" in proceedings before District Tribunals. Moreover, cases that will be referred for peacemaking to a Peacemaking Forum will not be cases that fall under the jurisdiction of District Tribunals, they will be cases that fall within the normal jurisdiction of the referring court (which in our case will be High Court or Magistrates' Court), and so this system cannot be seen as usurping or duplicating the functions of District Tribunals. More importantly, District Tribunals are creatures and legacies of colonialism. As pointed out by Davidheiser (2007), District Tribunals were hitherto called Native Tribunals, composed inter alia of offices created by colonialists- Village Chiefs (Sefos) and Village Heads (Alkalos). These offices still exist and are still part of the District Tribunal panels. Therefore, District Tribunals are not strictly indigenous traditional methods of resolving disputes. They represent Western ideas of justice, which Davidheiser (2007) suggests we should move away from.

There could be concerns that the Peacemaking Court System will gradually make the courts to which they apply redundant. However, the Peacemaking Court System does not aim to make those courts redundant- in fact it cannot do so, as those courts are established by section 120 of the 1997 Constitution and given specific jurisdictions. Also, not all the cases that go to those courts will be referred to the Peacemaking Forum. There will inevitably be resistance by some parties or their lawyers in many cases. Not all cases will be suitable for referral to the Peacemaking Forum. For example, certain serious criminal cases might not be suitable for 


\section{International Journal of Social Science and Economic Research}

ISSN: $2455-8834$

Volume:05, Issue:03 "March 2020"

referral to the Peacemaking Forum. Moreover, the judge will merely have a discretion to refer the matter to the Peace Forum, he is not obliged to do so. Consequently, the Peacemaking Court System will simply be complementing the existing courts by creating the opportunity for them to effectively manifest and expand their peace making role.

The Peacemaking System will present a better opportunity for the judge and the court to be seen doing peace. It is important that the courts and judges are actually seen doing peace. Courts are not only temples of justice- they are also temples of peace because they ensure a peaceful society through justice. Therefore, courts should not only be seen doing justice, they should also be seen doing peace.

Another issue, is that in the Peacemaking Court System the judge appears to be merely a conduit to the Peacemaker and not the actual peacemaker-just like in the present case of the Court Connected ADR system. The judge is not even referred to as Peacemaker -he is referred to as a judge to distinguish him from the Peacemaker. Thus it can possibly be argued that the judge's role as peacemaker is equally diminished and obscured in the Peacemaking System. Despite this possible argument, I will argue that the judge is a vital conduit in the Peacemaking Process. The Peacemaker will not have the opportunity to be involved without the judge's intervention-it is the judge who refers the matter to the Peacemaker and not the other way round. Furthermore, and more importantly, the Peacemaker will be under the supervision of the judge, and it is the judge, not the Peacemaker who will be responsible for enforcing the results of the peacemaking process conducted by the Peacemaker. Consequently, the judge is inextricably linked to the Peacemaker, and is a sine qua non of the peacemaking process. This makes the judge a peacemaker in the process even if he is not so titled. In any event, as already stated, judges are already peacemakers by the mere fact that their role is to decide disputes and render justice and stability in the community. The issue I have is not that judges are not peacemakers. The issue I have is simply that judges' peacemaking role is often muted and obscured, and the peace that emanates from their decisions are not as constructive as they could be because of the restrictions placed on them by the adversarial system.

Certainly, the idea of peacemaking in very serious criminal cases such as murder or manslaughter, will not be appealing to the victims of these offences or their families. However, it is worth bearing in mind that many delinquent and criminal behaviors stem from social and family issues (Fergusson et al 1994), which can be addressed more effectively in a Peacemaking Forum where the Peacemaker can get to the root of the dispute due to open communication in the process. Peace philosophers believe that if the root of the dispute is not addressed, there will be persistent recurrence of the dispute (see Dietrich, 2014; Lederach,1997).Moreover, in The 


\section{International Journal of Social Science and Economic Research}

ISSN: $2455-8834$

Volume:05, Issue:03 "March 2020"

Gambia and in other countries such as the Unites States of America, the United Kingdom and Nigeria, plea bargaining exists even in very serious criminal cases.

Plea bargaining allows the parties in a criminal case to talk and reach an agreement, so that if the accused confesses to the charge or to a lesser charge, or provides some information valuable to the prosecution, then he will be charged with a lesser offence or handed down a lighter sentence. Such an agreement satisfies both the accused, the prosecution, and the victim. Therefore, plea bargaining permits peacemaking even in serious criminal cases, and hence the reason why Mordi (2018)contends that plea bargaining is synonymous with mediation. The point to make however, is that peacemaking will not always be rejected by victims or their families even in serious criminal cases and so serious criminal cases should not be seen as an impediment to the establishment of a Peacemaking Court System in The Gambia. In the Gambia, although there is no statute sanctioning a plea bargaining system, plea bargain exists even in serious criminal cases like murder or manslaughter, as can be seen in the criminal case registered as HC/439/17/MF/124/F1 in The High Court of The Gambia.

It is true, that in very serious criminal cases, like murder for example, peacemaking will sometimes or often, be rejected by the prosecution and or the victim's family and loved ones. Nevertheless, going by the three instances Connors (2014) suggests would be ideal for referral to peacemaking, the Peacemaking System should be useful for all cases (civil or criminal- serious or not serious).

While Hudson \& Galaway (1996) as cited by Nielsen (1999), warn against deprofessionalizing justice by giving the community the responsibility for justice under a Peacemaking System, Nielsen's (1999) response to their warning is that under the Peacemaking System, while Peacemakers are not referred to as professionals, they have some skill and expertise in traditional peacemaking strategies, and receive some organizational training so that they are able to control their proceedings. Therefore, the Peacemaking system does not license inept and unskillful Peacemakers to engage in peacemaking. In any event, as stated, parties would participate in the Peacemaking System only if they want to-they are not compelled. If they are not happy with the process, they can always revert back to the referring court before the end of the process.

Furthermore, professional justice does not always work-it does not ensure constructive peace between the parties and it has not effectively mitigated the backlog of cases in some of our courts. Also, the fact that indigenous traditional peacemaking methods like the Navajo Peacemaking system, or the relationship oriented traditional justice system of 'Hadamayaa Siloo' Davidheiser (2007) associates with rural Gambia, exist and do work, is an indication that justice need not always be professional to be attractive or effective. 


\section{International Journal of Social Science and Economic Research}

ISSN: $2455-8834$

Volume:05, Issue:03 "March 2020"

The idea of the Peacemaking Court System might be too far- fetched for some.

Of course, just because it works for the Navajo Justice system, and is working in the North American justice system, does not mean that it will work for another system.

There will be other logistical issues to consider-for example where will the Peacemaker's proceedings be conducted? In the Navajo system, the peacemaking process takes place in the same location as the referring court. However, I believe that the parties and the Peacemaker will feel more at ease if they are far away from the formal and restrictive atmosphere of the courts. As already stated, a court is not the ideal forum to achieve constructive peace. Therefore, a Peace Forum should be far away from the courts, and should be nearer to facilities that can inspire constructive genuine peace. For example, they can be located near the sea, near plantations and forests, or near religious sites such mosques or churches-any location that can inspire reflection and peace.

The Peacemaker will require support staff who should also be trained, and that is another expense to consider. A major hurdle for such a system would be budgetary constraints. There is limited budget for the courts, and at present the courts' budget does not envisage such a system. However, various fund raising methods could be explored. There are several organizations concerned with improving access to justice all over the world- most notably the UN and the Commonwealth Secretariat. If there are no legal obstacles to establishing such system, there will be no difficulties securing funding. Under section 121 of the 1997 Constitution, the Chief Justice, who is responsible for the administration and supervision of the courts, may make rules for regulating the practice and procedure of the courts. Therefore, as long as there is consensus in the legal and judicial fraternity, rules can be formulated to establish such a system as part of the High Court and or Magistrates' Courts processes.

The fact that Davidheiser (2007) suggests the Peacemaking System after studying the Gambian justice system in 2007, and the fact that I am again suggesting it in 2018, is no coincidence. The suggestions simply emanate from an increasing awareness of the need to have in The Gambia, a system of justice that allows for disputes to be effectively resolved to foster genuine constructive peace, as well as improve access to justice. Certainly, there could be other systems much better than the Peacemaking System. The hope is that this article will trigger other ideas and suggestions that are even better, as the motivation behind it is exactly that-not to be dogmatic.

\section{Conclusion and the way forward}

At present, the courts will resolve disputes, but in resolving disputes they leave a fragile or damaged relationship between parties. The Peacemaking System will ensure a stronger and 


\section{International Journal of Social Science and Economic Research}

ISSN: $2455-8834$

Volume:05, Issue:03 "March 2020"

better relationship between the parties, and will foster a more harmonious society. The peacemaking system will not always be successful, and is not expected to be perfect because nothing is perfect. In fact, some disputes might have to revert back to the referring court causing further delay and inconvenience. However, not all cases referred to peacemaking will fail, and many are bound to succeed. Moreover, the idea is not to totally eliminate delay, for there is bound to be delay even in systems that we try to emulate. In any event, delay caused by a failed agreement of the parties to pursue a peaceful resolution (which is the better option), is a justifiable delay.

In the quest to evolve and improve access to justice, the Dutch developed an online justice system (the website Rechtwijzer.nl), whereby disputants are guided through questions and provided with tools to resolve their disputes online. The Dutch system, like any other system is not perfect, but it received positive reports (Bickel et al, 2015), and better versions of it are being explored in the United Kingdom. According to The Guardian (UK) (Bowcott, 2016), because cases in the United Kingdom are taking up to 19 months to get to the Court of Appeal due to backlogs, efforts are underway to introduce online justice system there. These efforts, according to The Law Society Gazette (Cross, 2017), are supported by the Master of the Rolls, and are expected to greatly mitigate the backlog of cases and avoid further delays in that system. Consequently, the point to make, is that even more advanced countries we strive to emulate have backlogs, and are still evolving and doing as much as possible to improve access to justice in their systems. If more advanced countries we strive to emulate are still evolving and improving their justice systems, we cannot afford to sit on our laurels. If we don't explore and evolve, we will not progress.

Yet, as appealing as the idea of the Peacemaking System might be, it will be a new phenomenon in this jurisdiction, and so is likely to be faced with stiff opposition. A great hurdle will be logistical and budgetary constraints. Nevertheless, it is worthwhile to know that it exists. Even if such a system is not established in this jurisdiction, the mere knowledge that it exists and works elsewhere, should stimulate ideas for more suitable alternatives, and should be a motivation and inspiration for us to keep exploring what works best for us. Davidheiser (2007) underscores that there is insufficient exploration of local methods of justice that may be more suited to our needs. He laments that because the trend has been to adopt Western justice systems and to concentrate on strengthening those Western justice systems we adopt, public perception of our justice system is negative, and there is little public confidence in our justice system.

The prudent way forward is not to dismiss the idea of the Peacemaking Court System. The prudent way forward is to allow the idea to generate more thoughts, research and exploration, 


\section{International Journal of Social Science and Economic Research}

ISSN: $2455-8834$

Volume:05, Issue:03 "March 2020"

toward a system that best suits our need for a more constructive system of justice that yields a harmonious society and fosters better access to justice. Better access to justice will encourage confidence in the justice system as well as a peaceful and stable society.

\section{References}

Baldeh, N. (2016, January). “ADR works effectively in rural areas” The Point Newspaperwww.thepoint.gm

Bickel, E. A., van Dijk M.A., \& Giebels, E. (2015). Online legal advice and conflict support: A Dutch experience. University of Twente, Department Psychology of Conflict, Risk \& Safety https://research.utwente.nl

Bowcott, O. (2016, March). "Cases taking 19 months to get to appeal court owing to backlogs" The Guardian (UK) https://amp-theguardiancom.cdn.ampproject.org/v/s/amp.theguardian.com/law/2016/mar/07/courtcases-19-monthsappeal-court-backlogs

Connors, T. (2014). Exit, pursued by a bear: why peacemaking makes sense in state court justice systems Judges' Journal Vol. 55 No.4 https://americanbar.org

Cross, M. (2017). "Online court won't repeat failure of Dutch model, MoR claims" The Law Society Gazette. https://www.lawgazette.co.uk20 th June 2017

Davidheiser, M. (2007). Governance and legal reform in The Gambia and beyond: an anthropological critique of current development strategies Max Planck Institute for Social Anthropology Working Papers www.eth.mpg.de>pubs $>$ wps $>$ pdf $>$ m...

Deutsch, M., Coleman, P.T., \& Marcus, E.C. (2011). The handbook of conflict resolution: theory and practice John Wiley \& Sons

Dietrich, W. (2012). Interpretations of peace in history and culture, many peaces Volume 1. London, Palgrave Macmillan.

Dietrich, W. (2013). Elicitive conflict transformation and the transrational shift in peace politics,many Peaces Volume 2. London, Palgrave Macmillan

Dietrich, W. (2014). A brief introduction to trans-rational peace research and elicitive conflict transformation. Journal of Conflictology, 5(2)

Fergusson, D.M., Horwood, L.J. \& Lynskey M. (1994). The childhoods of multiple problem adolescents: a 15-year longitudinal study. Journal of Child Psychology and Psychiatry 35(6), 1123-1140

Galtung, J. (1969). Violence, peace, and peace research. Journal of Peace Research, 6(3), 167-191

Hudson, J. \& Galaway, B. (1996). Introduction in Restorative Justice: International Perspectives Galaway, B. \& Hudson, J (eds), Monsey, NY: Criminal Justice Press, Pp.1-14

Keebler, R.S. (1930). Our Justice of The Peace Courts-a problem in justice. Tennessee Law Review Vol.9 (1)

Kerr, R. \& Mobekk, E. (2007). Peace and Justice. Polity

Lederach, J.P. (1997). Building peace: Sustainable reconciliation in divided societies. Washington DC, 4.

Lederach, J.P. (1998). Beyond Violence: building sustainable peace. In The handbook of interethnic coexistence Weiner, E. (ed.), New York: Continuum Publishing, Pp. 236-245 


\section{International Journal of Social Science and Economic Research}

ISSN: $2455-8834$

Volume:05, Issue:03 "March 2020"

Lederach, J.P. (2003). Little book of conflict transformation Good Books

Lederach, J.P. (2005). The moral imagination: The art and soul of building peace (Vol.3). New York: Oxford University Press

Mordi, C.A. (2018). The Use of Plea Bargain in Nigerian Criminal Law. Beijing Law Review, 9, 153-161

Nielsen, M.O. (1999). Navajo nation courts, peacemaking and restorative justice issues. Journal of Legal Pluralism 1999-nr.44

Pew Research Center's Global Religious Futures Database (2010) (Pew Polivy, J. and Herman, C.P. (2002). If at First You Don't Succeed, False Hopes of Self-Change. American Psychologist Association, Vol 57, No. 9, 677689DOI:10.1037//0003-066X.57.9.677

Porter, E. (2015). Connecting peace, justice, and reconciliation Lynne Reinner Publishers (excerpt from https://www.rienner.com>uploads)

Sadurski, W. (1984). Social justice and legal justice. Law and Philosophy Vol 3, 3, 329354,https://doi.org/10.1007/BF00654832

Sasson, E., \& Sydow, N. (2017) Inspired by peacemaking: creating community based restorative programs in state courts. National Center for State Courts Center for Court Innovation $\underline{\text { https://tinyurl.com/yb8hfzzw }}$

Sydow, N. (2018). Peacemaking programs offer state courts an alternative path. National Center for State Courtshttps://ncsc.org

Templeton Project 2010) www.globalreligiousfutures.org>gambia

West African Law Institute (N.D.) Summary of findings alternative dispute resolution in The Gambia www.undp.org $>$ dam $>$ gambia $>$ docs

Zion, J.W. (2005). Navajo Nation Peacemaking: Living Traditional Justice. In The Navajo Peacemaker CourtDeference to the Old and Accommodation to the New. Nielsen, M.O. \& Zion J.W. Chapter 3, University of Arizona Press

\section{Statutes/Instruments}

Constitution of The Republic of The Gambia 1997

Rules of the High Court Cap 6:01 Laws of The Gambia

High Court (Amendment) Rules 2013

District Tribunals Act Cap: 6:03 Laws of The Gambia

Alternative Dispute Resolution Act (2005)

Practice Direction No.1 of 2013 